\title{
STUDIES ON THERMAL PROCESSING OF TUNA-A COMPARATIVE STUDY IN TIN AND TIN-FREE STEEL CANS
}

\author{
Maheswara $\mathrm{KJ}^{1}{ }^{*}$, Raju $\mathrm{CV}^{2}$, Naik $\mathrm{J}^{3}$, Prabhu $\mathbf{R M}^{4}$ and $\mathrm{K}^{\text {Panda }}{ }^{5}$
}

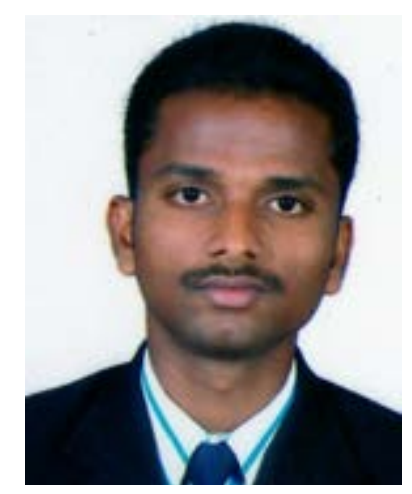

KJ Maheswara

*Corresponding author email: Kjmahesh@gmail.com

${ }^{1}$ Research Scholar, Dept. of Fish Processing Technology, College of Fisheries, Mangalore, Karnataka, INDIA.

${ }^{2}$ Associate Professor, College of Fisheries, Mangalore, INDIA.

${ }^{3}$ Research Scholar, College of Fisheries, Mangalore, INDIA.

${ }^{4}$ Associate Professor, College of Fisheries, Mangalore, INDIA.

${ }^{5} \mathrm{PhD}$ scholar, College of Fisheries, Mangalore, INDIA. 


\section{ABSTRACT}

Tin-free steel can is an ideal alternative to open top sanitary tin cans (OTS) for thermal processing of little tuna (Ethynnus affinis) in curry used as filling media. Effect of heat penetration on physical, biochemical and sensory characteristics of canned tuna product were studied. The chemical analysis of raw tuna fish showed a protein content of $24.20 \%$ and a lipid content of $1.37 \%$. Comparatively, tuna used in the present study is more suitable for canning due to the presence of more protein and less fat in its flesh. Precooking is an important step in general canning process as it serves to reduce moisture content along with inhibiting enzymatic reaction, decreasing microbial load and cleansing the meat. The protein content of precooked tuna was $2.92 \%$ more than raw tuna due to relative concentration of moisture content decreases due to precooking. The percentage of yield of light meat and dark meat was $36.58 \%$ and $10.18 \%$ from whole cooked tuna and the same for dark and white meat was $28.40 \%$. Tuna in curry packed in two metal containers subjected to thermal processing at $115^{\circ} \mathrm{C}$ for 70 minutes. The $\mathrm{F}_{0}$ (slowest heating point) values for canned tuna in curry packed in TFS and Tin cans obtained were 10.13 and 10.23 minutes and cook values were 145.5 minutes \& 153.6 minutes respectively. During the storage period, the total volatile base nitrogen, trimethyleamine nitrogen, free fatty acid values were found to increase, while thiobarbituric acid value decreased and $\mathrm{pH}$ was slightly acidic. There was no significant difference $(p<0.05)$ in appearance, colour, odour, taste, flavour, texture, overall quality of the raw tuna and final products. However, both canned products were acceptable even after storage of 5 months at ambient temperature and also, the product remained commercially sterile. It was concluded that according to quality of the product and heat penetration studies, tinfree steel container can be used as alternative to the open top sanitary tin cans for canning tuna meat.

Key words: Cooking, Curry, Quality, Shelf-life, Storage 


\section{INTRODUCTION}

Canning is an art of preserving foods and the industry expanded based on trial and error basis and skill of individual canners. During the 1990's, this method received much scientific scrutiny and has now developed into a sound and established technology to produce commercially sterilized safe foods having an almost infinite shelf life.

Tuna contains higher biological protein than beef and is one of the best sources of dietary amino acids. Further, tuna flesh contains substantial quantities of vitamins $\mathrm{B}_{12}$, $\mathrm{A}$ and $\mathrm{D}$ and is also a rich source of phosphorous, iodine and fluorine [1]. Canned fish may be considered an excellent source of vitamin D [2].

The use of tin-free-steel (TFS) cans for thermal processed foods is one of the most recent developments in the fish canning industry. Tin-free steel can is an alternative to open top sanitary tin cans (OTS) and aluminium cans, which have disadvantages like high price of the container, imperfect lacquer coating, discolouration of the product, dissolution of metals in the food upon storage and resultant development of metallic taste in the product. The health problems associated with ingestion of food contaminated with metals and the components leaching out of the epoxy resinous coating like bisphenol-A are well documented $[3,4,5]$. The higher container cost in the case of tin cans is due to the limited geographical distribution of tin resources, which raise the cost of the container [6]. The higher price of container has resulted in the collapse of the fish canning industry in developing countries like India. Hence, the chromium coated steel plate acts as an alternative to tin plate for canning of seafood products and has gained prominence [7]. Tin-free-steel cans have easy to open ends and are coated inside with a polymer that does not react with products [8].

At present, value addition is of utmost importance in the fish processing industry because of the realization of high unit value of such products. Thermal processing of fish in curry medium has been attempted by several workers. Ready to eat foods were traditionally processed in rigid containers like tin and aluminium cans [9, 10]. The shelf life of formulated fish curry packed in a retort pouch at room temperature was recorded as around 12 months [11]. Also, the North Indian style curry medium for packing of rohu in tin-free-steel cans was standardized [8]. Mohan et al. [12] had developed a thermal processed shrimp kuruma in retort pouch [12]. Moreover, readyto- eat squid masala packed in locally made coated tin-free-steel cans also exists in South India [13].

The present investigation work was aimed at standardizing the canning process for little tuna, packed in two different metal containers (tin and TFS cans) using curry as a filling medium. The cans underwent a vacuum seaming process and then thermally processed at $115^{\circ} \mathrm{C}$ for $70 \mathrm{~min}$ after which a comparative heat penetration study was carried out between the two canned products. Both canned products were stored at room temperature $\left(28 \pm 2^{0} \mathrm{C}\right)$ and sensory, biochemical and microbiological analyses were performed on monthly basis for a period of 5 months. 


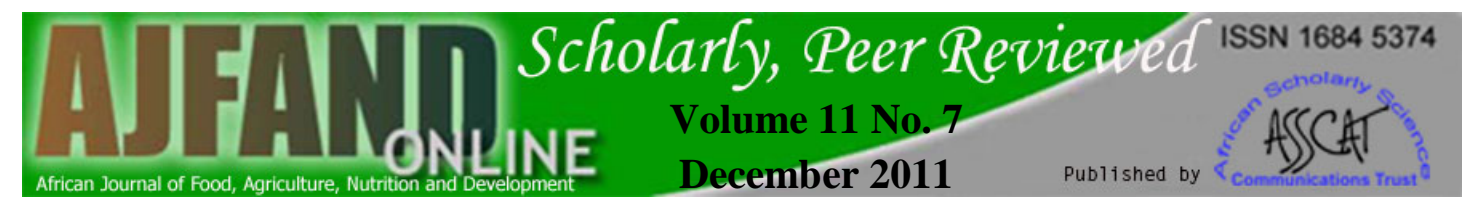

\section{MATERIALS AND METHODS}

\section{Raw materials}

Little tuna (Euthynnus affinis) procured from Mangalore fish landing centre and caught from the Arabian Sea along the west coast of India, was brought to the laboratory in iced condition. After removing head and viscera, it was kept in running water for removal of blood.

\section{Containers}

The containers used for packing the products were Open Top Sanitary (OTS) 8 oz tin cans with SR- lacquer manufactured and supplied by M/S Poysha Industries, Ltd., India and two piece Easy Open End 6 oz TFS cans were obtained from AM-Tech pack, Mysore, India.

The TFS can is made up of Electrolytic Chromium Coated Steel (ECCS) plate with clear Polyethylene Therephthalate (PET) coating on either side of the finished plate has a thickness of $0.19 \mathrm{~mm}$. Both the cans were washed thoroughly by using soap detergent solution as well as fresh water to remove the adhering impurities and dried well to remove the traces of water.

\section{Heat penetration assembly}

Before filling the cans, Ellab SSA - 12050-G700-TS stainless steel electrode was fixed at the geometric centre of the TFS and tin cans. The product was packed into the cans, exhausted and sealed with a vacuum seamer.

The time-temperature measurement during the sterilization process was carried out using Ellab CTF 84 data recorder connected to printer. The heat penetration data included retort temperature, product temperature, $\mathrm{F}_{0}$ value and cook value at the time of one min during thermal processing at $115^{\circ} \mathrm{C}$ for 70 minutes.

\section{Curry preparation}

Three different types of curry recipe were prepared as the filling media and analysed by a panel of 8-10 judges based on the sensory scores (Appendix I). One among the recipes was selected as a filling medium based on the above sensory scores. The curry was prepared as per the method given by Mallick et al. [8]. The contents of the recipe are given in Table.1.

\section{Precooking of dressed tuna}

Dressed fish was precooked in steam pressure of 10 psi for 60 minutes to attain a temperature of $90-92^{\circ} \mathrm{C}$ at central bone surface to soften the fish muscle for separation of dark meat from the whole tuna and kept at $4-6^{0} \mathrm{C}$ in a refrigerator overnight [14]. The skin was separated off from the precooked tuna and was split dorsoventrally along the lateral line to get loins. Red meat, lying along the lateral line was removed manually and white meat was carefully separated from the cooked tuna loins. 


\section{Preparation of cans for thermal processing}

The thermal processing study was carried out at Central Institute of Fishery Technology, Cochin, India. To prepare test cans for the heat penetration study, can body was perforated by means of a punching tool for side entry and the packing gland was tightly screwed into the can body with a rubber gasket so as to make the joint air proof. The position of the perforation was such that the thermocouple tip would be at the predetermined cold spot to record the core temperature, $F_{0}$ value and cook value of the canned tuna in curry product. With the standard operation achieved by the above experiment, final canned products were prepared for the storage study. Separated light meat of precooked tuna pieces about $110 \mathrm{~g}$ was filled in TFS and tin cans with standardized hot curry $\left(90^{\circ} \mathrm{C}\right)$ weighing about $60 \mathrm{~g}$. Both cans were maintained with a uniform net weight of $170 \mathrm{~g}$ and vacuum seamed with an automatic vacuum seamer and subsequently subjected to thermal processing. Canning procedure for tuna is given in figure 1 . 
Raw material Stored in ice

Washing (chilled water)

$\downarrow$

Beheading, Gutting, Removing fins and scales

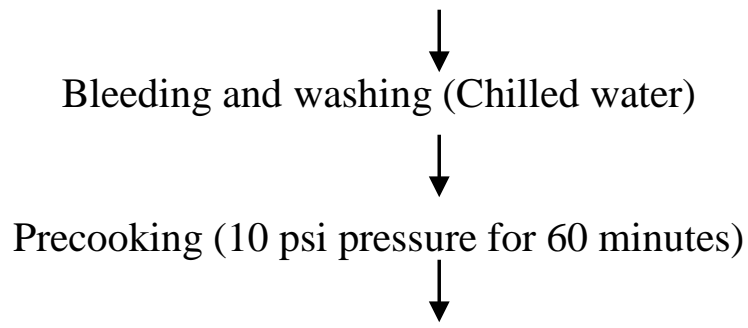

Cooling (at $\left.4-6^{\circ} \mathrm{C}\right)$

$\downarrow$

Removing skin, dark meat and bones

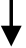

Can filling 110 g meat $(60 \%)+60 \mathrm{ml}$ of curry (40\%) packed in tin can and tin -free -steel can

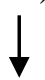

Exhausting (10 -12 minutes) and double seaming

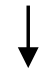

Retorting at $115{ }^{0} \mathrm{C}$ for 70 minutes

$\downarrow$

Can cooling and washing

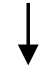

Labelling and storage

Figure 1: Tuna canning in curry packed in tin and TFS containers 
Biochemical analysis of sample

Moisture content of the fresh and final products of tuna was determined according to AOAC method [15]. Crude protein was determined by following the method suggested by Kjeldhal [15]. Crude fat content of the sample was determined according to the procedure described by Bligh and Dyer [16]. Ash content was determined by heating the sample at $550^{\circ} \mathrm{C}$ for 4-6 hrs using a muffle furnace [15]. Determination of TVB-N (Total volatile base nitrogen) and TMA-N (Trimethylamine nitrogen) was made by following the Conway diffusion method [17]. Free Fatty acid in the lipid extract was determined by the improved titrimetric method [18]. Thiobarbuteric acid value of fish sample was determined spectrophotometrically [19], while $\mathrm{pH}$ of the sample was measured according to the method given by Suzuki [20].

\section{Sensory evaluation}

The sensory analysis of fresh cooked little tuna as well as finished products were carried out using a 10-point hedonic scale by 8-10 trained taste panellists [21]. The scoring of the product was done based on the scorecard given in Appendix I.

\section{EXPERIMENTAL RESULTS}

\section{Physical, biochemical, microbiological and sensory characteristics of raw tuna}

The physical, biochemical and sensory characteristics of raw tuna are given in Table 2. The fish used had an average total length of $40.45 \mathrm{~cm}$, average standard length of $34.95 \mathrm{~cm}$ and average weight of $1.01 \mathrm{~kg}$. Organoleptic scores of raw tuna based on a10 point hedonic scale were 8.9 for appearance, 8.5 for colour, 8.65 for taste, 8.25 for texture, 8.75 for odour and 8.5 for overall acceptability.

The biochemical parameters of TVB-N and TMA-N of fresh tuna were found to be $6.10 \mathrm{mg} \%$ and $2.5 \mathrm{mg} \%$ respectively. The $\mathrm{pH}$ of the fish meat was 6.02, FFA and TBA contents were $3.5 \%$ as oleic acid and $0.10 \mathrm{mg}$ of melonaldehyde/kg, respectively. Total plate count found in the fresh fish was $4.45 \times 10^{4} \mathrm{cfu} / \mathrm{g}$.

\section{Yield at different stages of processing}

The yield of dressed tuna meat (after removal of head, viscera and fins) from the whole round tuna was $69.2 \%$ and pre-cooking yield of dressed tuna meat was $50.36 \%$. The separated dark and white meat yield was $10.18 \%$ and $36.58 \%$, respectively (Table 3).

\section{Proximate composition of raw tuna and precooked tuna}

Moisture and ash contents of the fresh raw tuna were $73.10 \%$ and $1.43 \%$, respectively. The fish had a high protein content of $24.20 \%$ and low fat content of $1.37 \%$ indicating that the fish is a lean variety. In precooked tuna, moisture content decreased to $69.98 \%$ and protein increased to $27.12 \%$. Fat and ash contents of precooked tuna were $1.50 \%$ and $1.40 \%$, respectively. Proximate composition of raw and precooked tuna are given in the Table 4. 


\section{Standardization of Thermal processing}

The tuna meat in curry, packed in TFS and OTS tin cans were processed at $115^{\circ} \mathrm{C}$ for 70 minutes to study the rate of heat penetration characteristics. The results of the study such as retort temperature, product temperature, $F_{0}$ value and cook value were recorded at an interval of 1 minute and heat penetration profile of these parameters are presented in figures 2A, 2B, 3A, 3B.

Canned tuna in curry medium and packed in TFS and OTS tin cans had a $\mathrm{F}_{0}$ value of 10.23 minutes and 10.13 minutes, respectively. The $\mathrm{F}_{0}$ value was calculated using Ball and Olson formula method and also by Patashnik method [22]. The heat penetration characteristics with reference to cook value $(\mathrm{Cg})$ were found to be 145.5 minutes for tuna in curry medium packed in TFS can and 153.6 minutes for tuna in curry medium and packed in tin can (figures 2A, 2B, 3A, 3B).

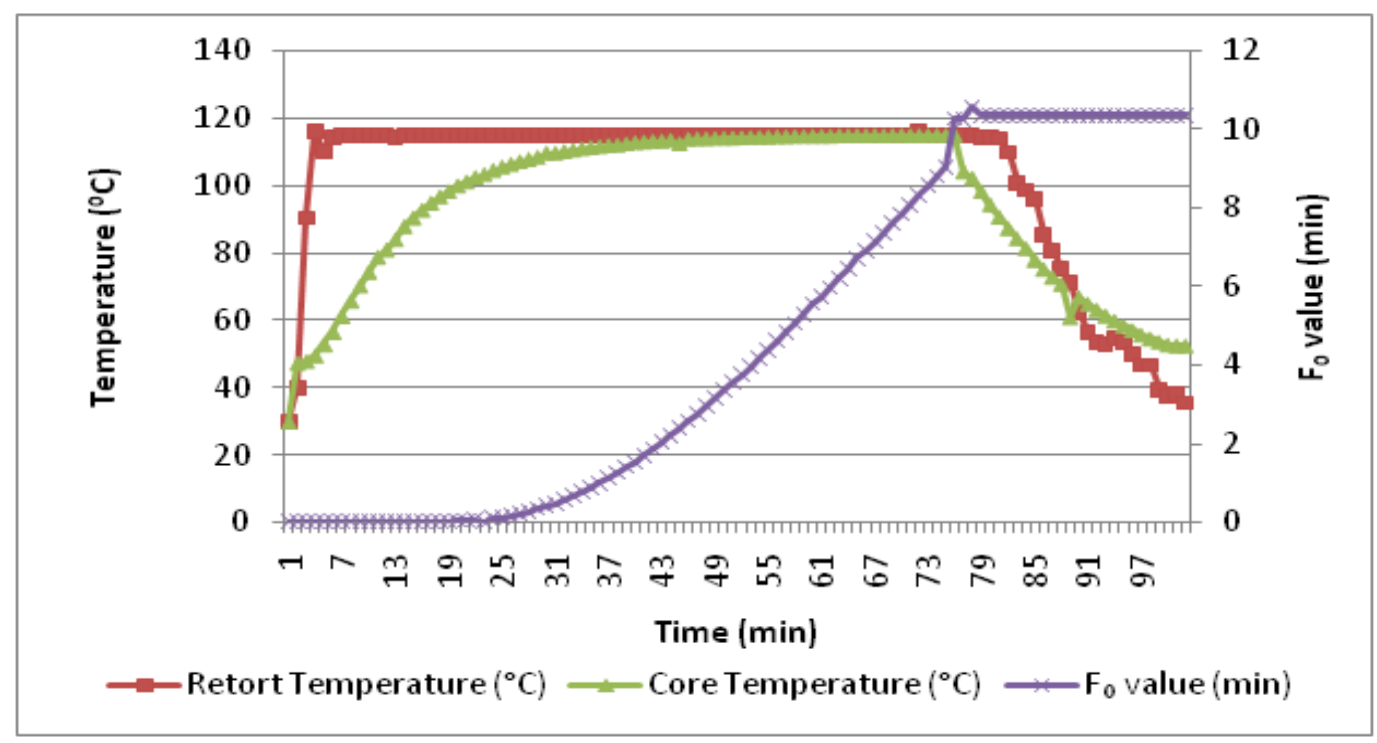

Figure 2A: Heat penetration characteristics with respect to $F_{0}$ value of canned tuna in curry in TFS can 


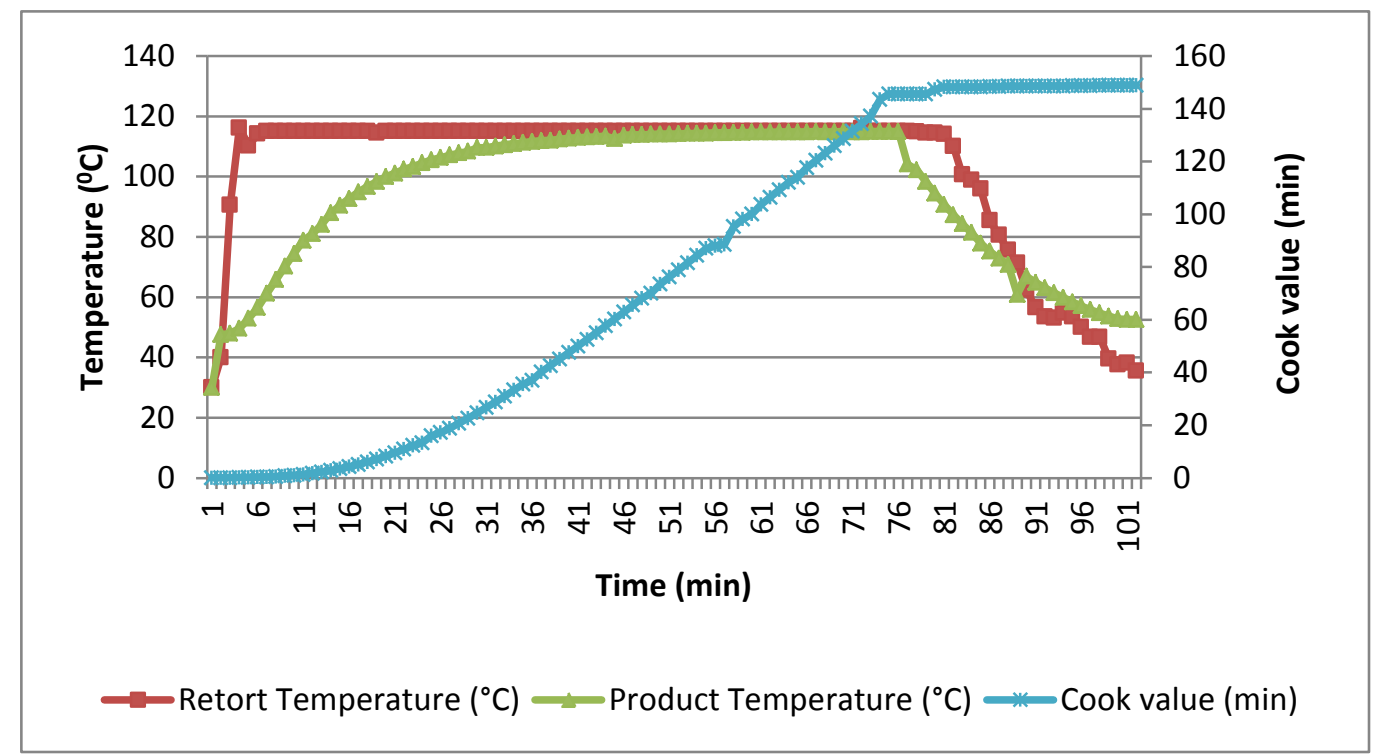

Figure 2B: Heat penetration characteristics with respect to cook value of canned tuna in curry in TFS can

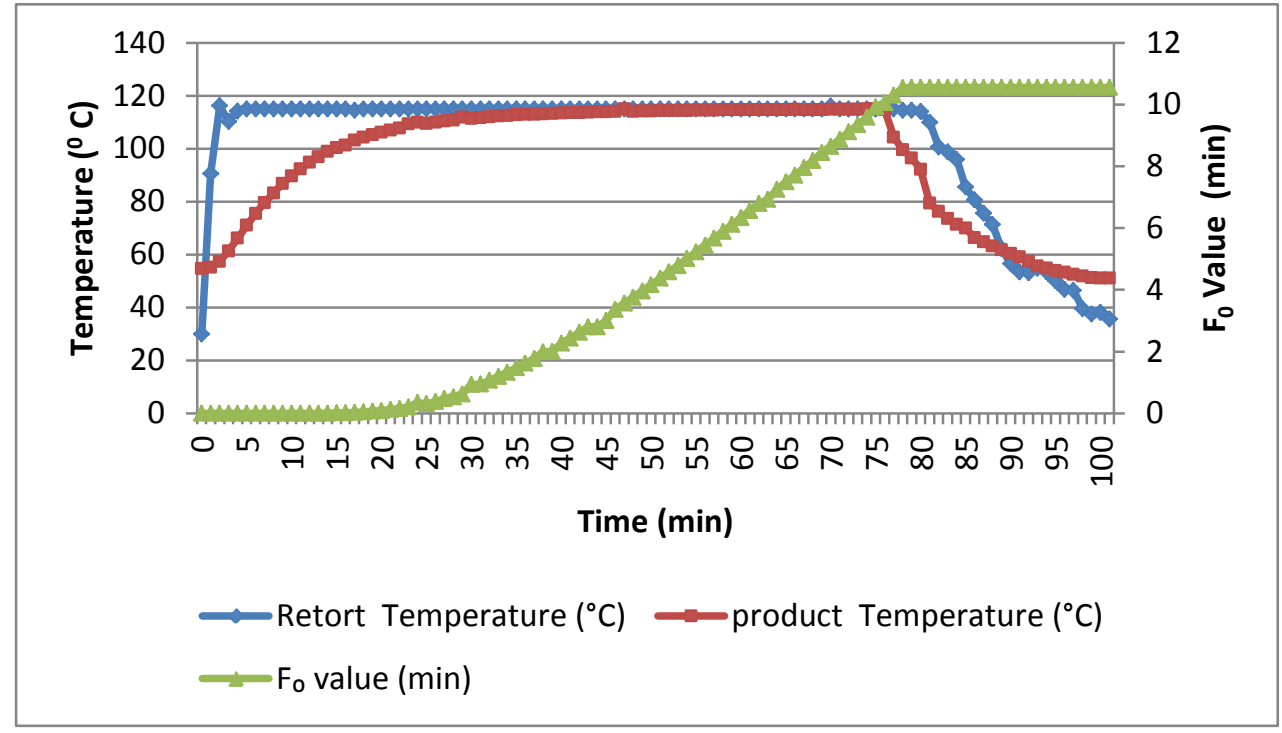

Figure 3A: Heat penetration characteristics with respect to $F_{0}$ value of canned tuna in curry packed in tin can 


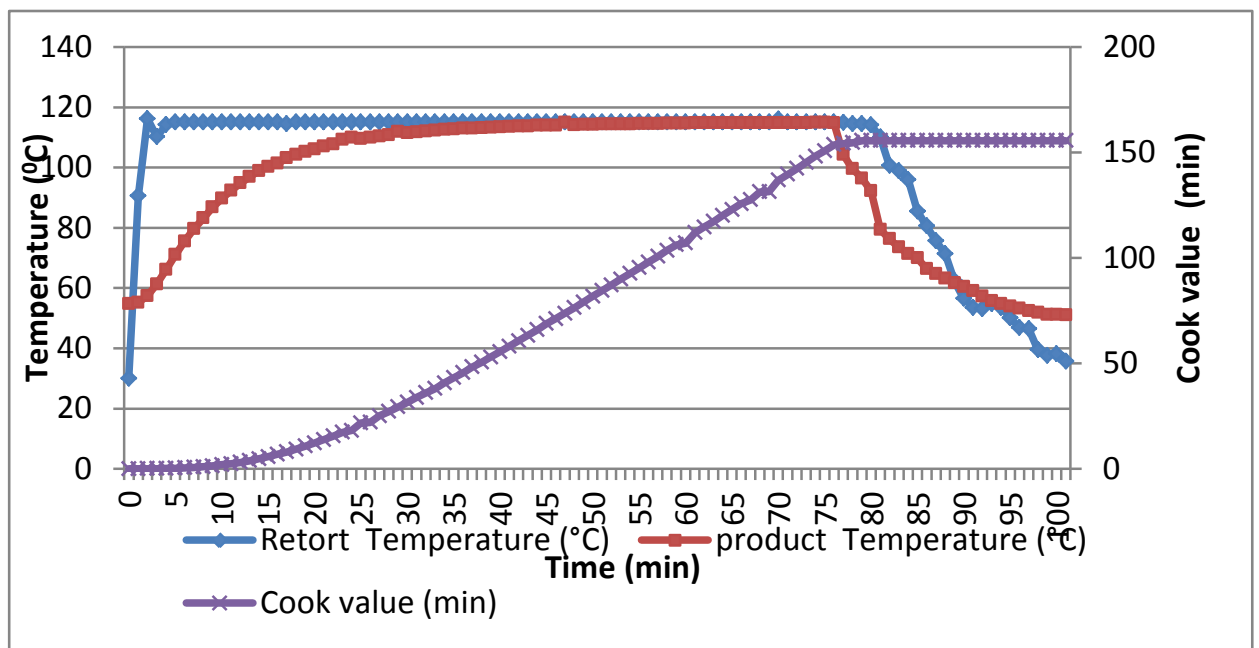

Figure 3B: Heat penetration characteristics with respect to cook value of canned tuna in curry in tin can

\section{Evaluation of quality characteristics of canned tuna products after processing and during storage}

\section{Proximate composition}

Changes in chemical and biochemical characteristics of canned tuna during storage period are presented in the Table 5. Initially the moisture, protein, fat and ash contents of freshly prepared tuna in curry packed in TFS cans were $72.39 \%, 24.29 \%, 1.50 \%$ and $1.82 \%$ of ash, respectively, and the respective contents observed were $72.90 \%$, $24.10 \%, 1.46 \%$ and $1.54 \%$ at the end of 5 months of storage period. Proximate composition of tuna samples in curry packed in OTS tin cans were $71.10 \%$ of moisture, $25.64 \%$ of protein, $2.02 \%$ of fat and $1.23 \%$ of ash which at the end of 5 months storage period were found to be $69.53 \%, 26.32 \%, 2.40 \%$ and 1.75 , respectively.

\section{Biochemical characteristics of canned tuna}

The results of TVB-N and TMA-N analysis were presented in the Table 5. Initial TVB-N \& TMA-N values of tuna in curry medium and packed in TFS can were 21.8 $\mathrm{mg} \%$ and $7.26 \mathrm{mg} \%$ which increased up to $27.3 \mathrm{mg} \%$ and $12.3 \mathrm{mg} \%$, respectively. Similarly, the TVB-N \& TMA-N values for Tuna in curry medium and packed in Tin can were $20.5 \mathrm{mg} \%$ and $8.5 \mathrm{mg} \%$, which increased up to $26.95 \mathrm{mg} \%$ and $11.6 \mathrm{mg} \%$ respectively at the end of 5 months of storage period.

The initial FFA content of freshly prepared canned tuna in curry packed in TFS and OTS tin cans were $3.07 \%$ and $3.57 \%$ of oleic acid and increased to $6.50 \%$ and $7.2 \%$ of oleic acid. The TBA values of canned tuna showed a slightly decreasing trend upon storage period (Table 5). Thiobarbuteric acid value of freshly prepared canned tuna in curry packed in TFS and OTS tin containers were $0.315 \mathrm{mg}$ and $0.329 \mathrm{mg}$ of 


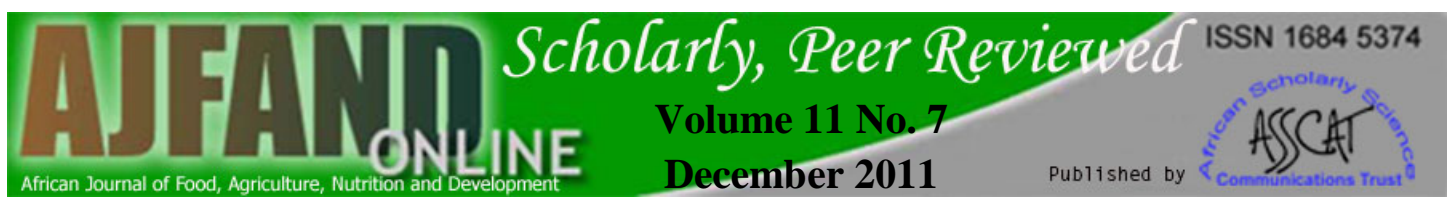

melonaldehyde/kg of sample, and decreased to 0.239 and $0.243 \mathrm{mg}$ of melonaldehyde/kg of sample respectively at the end of 5 months of storage period.

\section{Changes in $\mathbf{p H}$}

The changes in the $\mathrm{pH}$ of the canned tuna are presented in the Table $6 . \mathrm{pH}$ of the freshly prepared canned tuna in curry packed in TFS and tin containers were 5.98 and 5.91, which decreased to 5.38 and 5.41, respectively at the end of 5 months.

\section{Changes in organoleptic characteristics of canned tuna}

Table 7 gives mean panel scores of canned tuna in curry packed in TFS and tin can. It was observed that mean panel scores for appearance, colour, odour, taste, texture and overall quality decreased slightly during 5 months of storage period in both cans. However, scores for all these characteristics can be considered as good for all the products at the end of 5 months of storage period. Among the organoleptic attributes, there was not much difference between the tuna in curry packed in TFS and tin can.

\section{DISCUSSION}

The length of little tuna used in the present study was $40.45 \mathrm{~cm}$ which is lower than $52 \mathrm{~cm}$ [23]. The yield of dressed meat in the present study was 69.2\%, when compared to the yield obtained by the author who reported a dressed meat yield of $83.6 \%$ and dark meat yield of $20 \%$ in cooked skipjack tuna [24]. However, the white meat yield $36.4 \%$ reported was almost comparable to the present study.

\section{Biochemical composition of fresh tuna sample}

The proximate composition of fish and shellfish depends on several factors like diet, size, physiological state of fish and ecological conditions [25]. The results of the present investigation on proximate composition of fresh little tuna (Euthynnus affinis) agreed with earlier work carried out on proximate composition of the same species [23]. Tuna meat is high in biological value protein [24]. The variation of fat content can be attributed to species difference, food and feeding habit and season of harvest [26].

The value of $30 \mathrm{mg} \%$ for TVB-N and $15 \mathrm{mg} \%$ for TMA-N is considered as the limit for acceptability of freshness of fish [25]. As the values obtained in the present study are much less than acceptable limits for freshness of fish, the raw material used in the study can be considered of prime quality.

\section{$F_{0}$ value and Cook value of canned tuna products}

For the attainment of microbiologically stable state, the amount of heat received by the product during thermal processing needs to be verified. This is determined by the temperature profile within the product during thermal processing. The recommended $\mathrm{F}_{0}$ values for fish and fishery products range from 5 to 20 minutes [27]. In smoked tuna canned in brine and oil used as the filling media and packed in retort pouches, heat penetration was faster in the brine pack compared to the oil pack [28]. In case of rohu (Labeo rohita) in curry packed in TFS cans have obtained an $\mathrm{F}_{0}$ value of 8.79 minutes and the authors opined that the thermal process was adequate [8]. In the

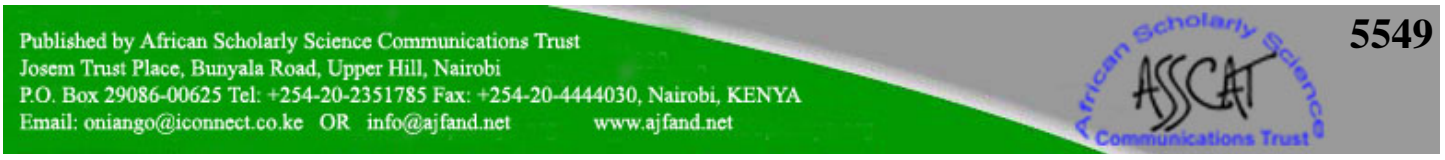


present study, the obtained $\mathrm{F}_{0}$ value was satisfactory for both the canned tuna products with reference to sensory attributes and commercial sterility. The $\mathrm{F}_{0}$ value of $10 \mathrm{~min}$ obtained showed not much difference between the tuna in curry packed in TFS can and tin can.

Cook value is the measure of heat treatment with respect to nutrient degradation and textural changes during processing. Cook value is determined by measuring the extent of cooking and nutritional loss during processing in a manner similar to the $\mathrm{D}$ value, except that the reference temperature is $100^{\circ} \mathrm{C}$ instead of $121^{\circ} \mathrm{C}$ and $\mathrm{Z}$ value is $33^{\circ} \mathrm{C}$ $[29,30]$.

\section{Biochemical changes in the canned tuna products during storage period}

Canned tuna in brine, oil and tomato sauce packed in tin cans did not show any difference in their proximate composition even after one year of storage [24]. The moisture content of rohu (Labeo rohita) in curry was almost the same throughout the storage period [8].

Thermal processing caused an increase in TVB-N and TMA-N values in both the canned tuna products during the present investigation. The increase could be due to the breakdown of proteins, amino acids and other nitrogenous compounds such as trimethylamine oxide, nucleic acids and amines present in the foods which received thermal processing [31]. Changes in TVB-N and TMA-N during canning of albacore (Thunnus alalunga) tuna and reported that increase in total volatile base nitrogen and loss of trimethylamine oxide [32]. Several authors are of the opinion that heat processing in general increases FFA content on storage [33, 34]. Mathews et al. [35] conducted a comparative study of ground-nut oil packed in TFS and in tin containers; they found no significant difference in FFA value and quality of oil between the two containers [35]. A significant formation of free fatty acids occurred during the sterilization of different muscle zones of albacore tuna as reported by Aubourg et al. [36]. A decreasing trend in TBA value has been reported in canned fish [37, 38]. The decrease in TBA value of canned fish meat might be due to dilution of secondary oxidation product by the fill oils, or their extraction from the meat to the fill oils [36]. However, in case of canned tuna products, the decreasing trend in TBA content may be due to the dilution of secondary oxidation product by the filling medium (curry). The $\mathrm{pH}$ decreased slightly in rohu curry packed in TFS container and this effect was due to the acidic compounds present in tomato and spices used in the curry preparation [8]. Similarly in the present study, the decreased $\mathrm{pH}$ of tuna in curry packed in tin and TFS cans may be attributed to the same acidic compounds present in the curry ingredients.

In the present investigation, there was not much difference in biochemical characteristics of canned tuna in curry packed in TFS can and OTS tin cans. Hence, both the canned tuna curry products did not show marked changes in the quality during the storage period. Therefore, it can be concluded that there was no effect of containers on the final product. 


\section{Sensory characteristics}

Thermally processed rohu curry in TFS cans was acceptable even after one year of storage with respect to sensory and biochemical parameters [8]. The quality of mackerel in brine with respect to organoleptic quality was acceptable when packed in TFS cans for up to 12 months of storage at $37^{\circ} \mathrm{C}$ [39]. In the present study, the organoleptic quality of canned tuna products was good as judged by sensory evaluation. There was no significant difference in the appearance, colour, odour, taste, texture, overall quality $(\mathrm{p}<0.05)$ of product in the tin can and in the TFS can during storage. The organoleptic quality of both the canned tuna products was good even after storage of 5 months at room temperature.

\section{CONCLUSION}

There was not much difference between OTS tin can and TFS can products, taking into consideration the heat penetration studies and quality of the final product even after storage of 5 months at room temperature. Therefore, canners can adapt the Easy Open End TFS cans as an alternative to the high priced tin container for canning tuna. With this adoption, the fish canning industry may look forward to the use of the TFS cans for revival of the canning industry in India. Also, it may increase the demand for ready-to-serve canned tuna in curry products as well as the developments of diversified canned products for the domestic market.

\section{ACKNOWLEDGMENT}

The authors are grateful to the Central Institute of Fishery Technology, Cochin, India for giving the opportunity to carry out the heat penetration studies at their institute. 
Table 1: Standardized tuna curry recipe

\begin{tabular}{|l|l|}
\hline Ingredients & Quantity (g) \\
\hline Dressed fish & 1000 \\
\hline Onion & 50 \\
\hline Garlic & 15 \\
\hline Ginger & 25 \\
\hline Coriander powder & 30 \\
\hline Chilli powder & 60 \\
\hline Turmeric powder & 4 \\
\hline Mustard & 2 \\
\hline Oil & 50 \\
\hline Salt & 20 \\
\hline Cumin & 4 \\
\hline Pepper & 4 \\
\hline Tomato & 150 \\
\hline Water & $1000 \mathrm{ml}$ \\
\hline
\end{tabular}




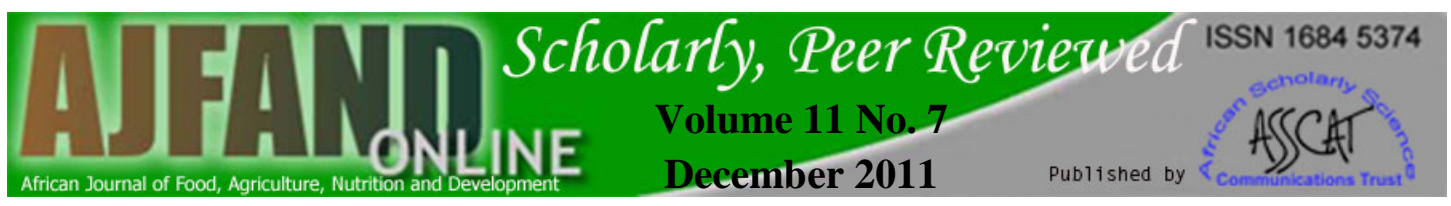

Table 2: Biochemical, microbiological and sensory characteristics of raw tuna

\begin{tabular}{|l|c|c|c|}
\hline \multicolumn{2}{|c|}{ Biochemical characteristics } & \multicolumn{2}{c|}{ Sensory characteristics } \\
\hline Parameters & $\begin{array}{c}\text { Fresh Raw } \\
\text { material }\end{array}$ & $\begin{array}{c}\text { Sample } \\
\text { characteristics }\end{array}$ & $\begin{array}{c}\text { Score (out } \\
\text { of 10) }\end{array}$ \\
\hline TVBN (mg\%) & 6.10 & Appearance & 8.9 \\
\hline TMAN (mg \%) & 2.5 & Colour & 8.5 \\
\hline pH & 6.02 & Taste & 8.65 \\
\hline Free fatty acid value (\% of & 3.5 & Texture & 8.25 \\
\hline oleic acid) & 0.10 & Odour & 8.75 \\
\hline TBA mg (melonaldehyde/kg) & $4.45 \times 10^{4}$ & Overall & 8.50 \\
\hline Total plate count (cfu/gm of \\
meat)
\end{tabular}

Table 3: Yield of the different parts of tuna as a percentage of starting raw tuna fish

\begin{tabular}{|c|c|c|}
\hline Materials & Weight (kg) & $\begin{array}{c}\text { Percentage } \\
\mathbf{( \% )}\end{array}$ \\
\hline Whole fish & 10 & 100 \\
\hline Dressed meat waste & 0.674 & 6.7 \\
\hline Dressed meat yield & 6.92 & 69.2 \\
\hline Pre-cooked fish & 5.036 & 50.36 \\
\hline Dark meat & 1.018 & 10.18 \\
\hline White meat & 3.658 & 36.58 \\
\hline
\end{tabular}




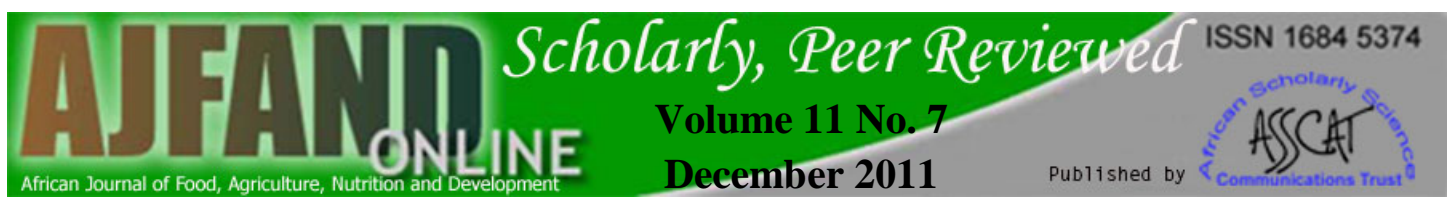

Table 4: Proximate composition of raw and precooked tuna

\begin{tabular}{|l|l|l|}
\hline Parameters & Raw tuna meat & Pre cooked tuna \\
\hline Moisture (\%) & 73.10 & 69.98 \\
\hline Protein (\%) & 24.20 & 27.12 \\
\hline Fat (\%) & 1.37 & 1.50 \\
\hline Ash (\%) & 1.43 & 1.40 \\
\hline
\end{tabular}

Table 5: Changes in proximate composition during storage of canned tuna in curry packed in TFS and tin can

\begin{tabular}{|c|c|c|c|c|c|c|c|}
\hline \multirow{2}{*}{ Parameter/storage } & \multirow{2}{*}{$\begin{array}{c}\text { Product } \\
\text { name }\end{array}$} & \multicolumn{6}{|c|}{ Months } \\
\cline { 3 - 8 } & & $\mathbf{0}$ & $\mathbf{1}$ & $\mathbf{2}$ & $\mathbf{3}$ & $\mathbf{4}$ & $\mathbf{5}$ \\
\hline \multirow{2}{*}{ Moisture (\%) } & TCTFS & 72.39 & 73.01 & 72.35 & 73.01 & 72.15 & 72.90 \\
\cline { 2 - 8 } & TCT & 71.10 & 73.50 & 70.95 & 71.25 & 70.20 & 69.53 \\
\hline \multirow{2}{*}{ Protein (\%) } & TCTFS & 24.29 & 24.30 & $24-10$ & 24.35 & 24.92 & 24.10 \\
\cline { 2 - 8 } & TCT & 25.64 & 25.03 & 24.50 & 24.95 & 25.95 & 26.32 \\
\hline \multirow{2}{*}{ Fat (\%) } & TCTFS & 1.50 & 1.49 & 1.91 & 1.41 & 1.30 & 1.46 \\
\cline { 2 - 8 } & TCT & 2.02 & 2.15 & 2.80 & 2.39 & 2.99 & 2.40 \\
\hline \multirow{2}{*}{ Ash (\%) } & TCTFS & 1.82 & 1.20 & 1.65 & 1.33 & 1.23 & 1.54 \\
\cline { 2 - 8 } & TCT & 1.23 & 1.50 & 1.55 & 1.41 & 1.86 & 1.75 \\
\hline
\end{tabular}

TCTFS: Tuna in curry in TFS can

TCT: Tuna in curry in Tin can 


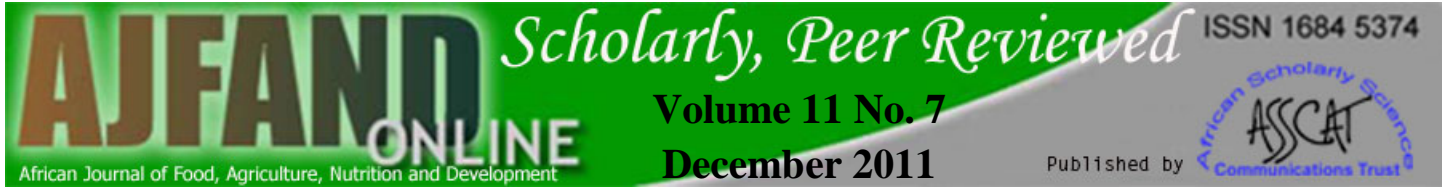

Table 6: Changes in biochemical characteristics of stored canned tuna

\begin{tabular}{|c|c|c|c|c|c|c|c|}
\hline \multirow{2}{*}{ Parameter } & \multirow{2}{*}{$\begin{array}{c}\text { Products } \\
\text { name }\end{array}$} & \multicolumn{6}{|c|}{ Months } \\
\hline & & $\mathbf{0}$ & 1 & 2 & 3 & 4 & 5 \\
\hline \multirow{2}{*}{ TVB-N (\%) } & TCTFS & 21.80 & 20.7 & 22.4 & 25.2 & 25.7 & 27.3 \\
\hline & TCT & 20.5 & 22.6 & 22.55 & 23.95 & 24.32 & 26.95 \\
\hline \multirow{2}{*}{ TMA-N (\%) } & TCTFS & 7.26 & 8.4 & 9.0 & 10.2 & 11.6 & 12.3 \\
\hline & TCT & 8.5 & 8.8 & 9.56 & 10.5 & 10.98 & 11.60 \\
\hline \multirow{2}{*}{$\begin{array}{l}\text { FFA \% as oleic } \\
\text { acid }\end{array}$} & TCTFS & 3.07 & 3.69 & 4.15 & 4.68 & 4.98 & 6.50 \\
\hline & TCT & 3.57 & 4.02 & 4.56 & 5.5 & 6.5 & 7.2 \\
\hline \multirow{2}{*}{$\begin{array}{c}\text { TBA mg of } \\
\text { melonoldehyde/kg } \\
\text { of sample }\end{array}$} & TCTFS & 0.315 & 0.291 & 0.275 & 0.253 & 0.235 & 0.239 \\
\hline & TCT & 0.329 & 0.312 & 0.287 & 0.265 & 0.256 & 0.243 \\
\hline \multirow{2}{*}{ pH } & TCTFS & 5.98 & 5.65 & 5.63 & 5.54 & 5.37 & 5.38 \\
\hline & TCT & 5.91 & 5.79 & 5.63 & 5.56 & 5.44 & 5.41 \\
\hline
\end{tabular}

TCTFS: Tuna in curry in TFS can; TCT: Tuna in curry in Tin can

Table7: Organoleptic scores of canned tuna in curry in TFS and tin can

\begin{tabular}{|c|c|c|c|c|c|c|c|}
\hline \multirow{3}{*}{ Parameter } & \multirow{2}{*}{$\begin{array}{c}\text { Type } \\
\text { of cans }\end{array}$} & \multicolumn{6}{|c|}{ Months } \\
\cline { 3 - 8 } & & $\mathbf{0}$ & $\mathbf{1}$ & $\mathbf{2}$ & $\mathbf{3}$ & $\mathbf{4}$ & $\mathbf{5}$ \\
\hline \multirow{2}{*}{$\mathrm{A}$} & TCTFS & 8.5 & 8.03 & 8.8 & 7.89 & 8.2 & 7.8 \\
\cline { 2 - 9 } & TCT & 8.66 & 8.41 & 8.3 & 8.5 & 8.0 & 8.1 \\
\hline \multirow{2}{*}{ Colour } & TCTFS & 8.03 & 8.50 & 8.26 & 8.05 & 7.5 & 7.1 \\
\cline { 2 - 9 } & TCT & 8.5 & 8.66 & 8.45 & 8.05 & 7.9 & 7.8 \\
\hline \multirow{2}{*}{ Odour } & TCTFS & 8.13 & 8.61 & 8.35 & 8.45 & 7.9 & 7.89 \\
\cline { 2 - 9 } & TCT & 8.16 & 8.50 & 7.91 & 7.56 & 8.15 & 8.1 \\
\hline \multirow{2}{*}{ Taste } & TCTFS & 8.06 & 8.15 & 8.33 & 8.41 & 8.2 & 7.82 \\
\cline { 2 - 8 } & TCT & 8.16 & 8.30 & 8.56 & 8.3 & 8.41 & 7.9 \\
\hline \multirow{2}{*}{ Texture } & TCTFS & 8.56 & 8.39 & 8.16 & 8.21 & 8.05 & 7.98 \\
\cline { 2 - 8 } & TCT & 8.66 & 8.45 & 8.26 & 8.35 & 8.15 & 8.62 \\
\hline \multirow{2}{*}{$\begin{array}{c}\text { Overall } \\
\text { Quality }\end{array}$} & TCTFS & 8.56 & 8.25 & 8.53 & 8.42 & 8.37 & 8.21 \\
\cline { 2 - 8 } & TCT & 8.30 & 8.45 & 8.35 & 8.21 & 8.1 & 7.65 \\
\hline
\end{tabular}

TCTFS- Tuna in curry packed in TFS can

TCT-Tuna in curry packed in Tin can 
Appendix 1

Scorecard for sensory evaluation canned tuna in curry packed in tin and TFS cans

Assessor:

Date:

Sample number:

\begin{tabular}{|l|c|}
\hline \multicolumn{1}{|c|}{ Attribute description } & Attribute Score \\
\hline Excellent & 10 \\
\hline Very good & 9 \\
\hline Good & 8 \\
\hline Moderately good & 6 \\
\hline Neither good nor bad & 5 \\
\hline Slightly rancid, bitter or other off flavours & 4 \\
\hline Moderately rancid, bitter or other off flavours & 3 \\
\hline Strong rancid, bitter or other off flavours & 2 \\
\hline Very strong rancid, bitter or other off flavours & 1 \\
\hline Extremely rancid, totally unacceptable & 7 \\
\hline
\end{tabular}




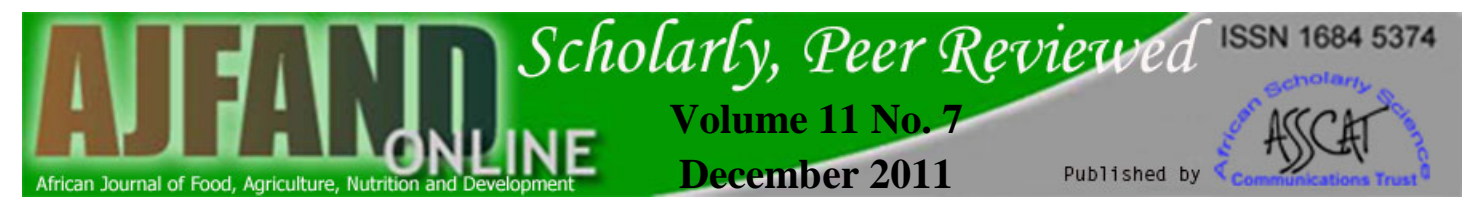

\section{REFERENCES}

1. $\quad$ Dewberry EB Tuna Canning in the United States. Food Trade Rev 1969; 39 (11): 37-42.

2. Neilands JB, Strong FM and CA Elvehjem The nutritive value of canned foods; vitamin content of canned fish products. Journal of Nutrition, 1947; 6 (3): 633-643.

3. Berthlof RL, Wills $\mathbf{M R}$ and $\mathbf{J}$ Savory In: Handbook on Toxicity of Inorganic Compounds (Seiler H.G. and Sigel H.) Marcel Dekker, New York, Ny. 1988; 55-65.

4. Krishnan AV, Stathis P, Permuth SF, Tokes $L$ and D Feldman Bisphenol A: An estrogenic substance is released from polycarbonate flasks during autoclaving. Endocrinology 1993; 132: 2279-2286.

5. Anonymous Opinoin of the scientific panel on dietic products, nutrition and allergies on a request from the commission related to the tolerable upper intake level of tin. J. Eur. Food Saf. Auth. 2005; 254: 1-25.

6. Naresh R, Mahadeviah M, Gowramma RV and BA Swamy Chromium coated tin-free steel cans as an alternative to tin plate for canning food products. J. Food Sci. Technol. 1980; 17: 283-286.

7. Naresh R, Mahadeviah M, Gowramma RV and BA Swamy Chromium coated steel as an alternative to tin plate for canning food products. J. Food Sci. Technol. 1989; 17:283-286.

8. Mallick AK, GOPAL TKS, Ravishankar CN and PK Vijayan Canning of rohu (Labeo rohita) in north Indian style curry medium using polyester-coated tin-free steel cans. Food Sci. Technol. Int. 2006; 12: 539-545.

9. Vijayan PK and KK Balachandran Development of canned fish curry Fishery Technol. 1986; 23: 57-60.

10. Mohan CO Thermal Processing of prawn Kuruma (peneaus indicus) in retortable pouch anda Alumium can. PhD Thesis, Mumbai: Central Institute of Fisheries Education; 2004; 1-125.

11. Gopal TKS, Vijayan TKS, Balachandran KK, Madhavan P and TSG Iyer Traditional Keral fish curry in indigenous retort pouch. Food control 2001; 12: 523-527.

12. Mohan CO, Ravishankar CO, Bindu J, Geethalakshmi V and TK Srinivasa Gopal Effect of Thermal Process time on quality of shrimp kuruma in retortable pouches and Aluminium cans. J. Food Sci. 2006; 71: S496-500. 
13. Sreenath PG, Martin Xavier KA, Ravishankar CN, Bindu J and TKS Gopal Standardization of process parameters for ready to eat squid masala in indigenous polymer coated tin-free steel cans. Int. J. Food Sci. Technol2007; 42: 1148-1155.

14. Xavier KAM, Sreenath PG, Sil S, Ravishankar CN, Bindu J and TKS Gopal Effect of rotation on the heat transfer characteristics and texure of canned skip jack tuna in tin-free steel cans. Fishery Technol. 2008; 45 (1): 5562.

15. AOAC. Official methods of analysis of association of official analytical chemists international. $17^{\text {th }}$, Suite 500, 481 North Frederick Avenue, Gaithersburg, Maryland, USA 2000: 2087-2417.

16. Bligh EG and WJ A Dyer rapid method of lipid extraction and purification. Can. J. Biochem. Physiol 1959; 37 (8): 911-917.

17. Beaty SA and NE Gibbons The measurement of spoilage in fish. J. Biol. Bd. Can. 1937; 3(1):77-91.

18. KE PJ, Ackman RG, Linke BA and DM Nash Differential lipid oxidation in various parts of mackerel. J. Food Technol. 1977; 12:34-47.

19. Tarladgis BG, Watts BM and MT Youtham A distillation method for the quantitative determination of melanoldehyde in rancid foods. J. Americ. oil Chem Socie. 1960; 37: 44.

20. Suzuki T Kamaboko (Fish cake) In: Fish and krill protein processing technology. Applied Science Publishers Ltd., London 1981: 62-112.

21. Vijayan PK Report on Training Programmed on Retortable Pouch Processing of Fish Analysis at tropical Development and Research Institute And Metal Box (R\&D), UK , Cochin: Central Institute of Fisheries Technology; 1984.

22. Patashnik M A simplified procedure for thermal process evaluation. Food Technol. 1953: 7:1-6

23. Basavakumar KV Physico-chemical and functional properties of proteins from tuna (Euthynnus affinis) meat: Effect of freezing and frozen storage. $P h D$ thesis KVFASU, Bidar 2007.

24. Akande GR, Emokpae AO, Towuru ET, Ogbonna C and A Ajayi Proximate composition, Microbiological and Sensory Evaluation of canned skipjack tuna (Katsuwonnus pelamis) stored at ambient and accelerated temperatures. Nigerian Institute of Oceanography and Marine research (Technical paper, 38) 1988; 1-12. 
25. Connell JJ Advances in fish science and technology. Fishing news Books, Survey England; 1975.

26. Gopakumar K Retortable pouch packaging. In: Fish packaging technology, concept publishing company, New Delhi, 1992: 127.

27. Frott $\mathbf{R}$ and AS Lewis Canning of meat and fish products, Chapman Hall, U.K; 1994: 202.

28. Bindu $\mathbf{J}$ and TKS Gopal Heat penetration characteristics of smoked tuna in oil and brine in retort pouches at different rotational speeds. J. Food Proces. Preserv. 2008; 32: 231-246.

29. Holdsworth S Thermal processing of packaged food. Blackie Academic and Professional, London; 1997.

30. Ranganna S Handbook of Canning and Aseptic Packaging, Tata McGrawHill Publishing Co. Ltd. New Delhi, India 2000; 507-508.

31. Chia SS, Baker RC and JH Hotchkiss Quality comparison of the thermo processed fishery products in cans and retortable pouches. J. Food Sci. 1983; 48: $1521-1525$.

32. Gallardo J, Perez-Martin R, Franco J, Aubourg S and C Sotelo Changes in volatile bases and trimethylamine oxide during the canning of albacore (Thunnus alalunga). Int. J. Food Sci. Technol. 1990; 25: 78-81.

33. Medina I, Sacchi R and S Aubourg NMR study of lipid alterations during fish canning: effect of filling medium. J. Food Sci. Agric. 1995; 69 (4): 445450 .

34. Bindu J, Ravishankar CN and TKS Gopal Shelf life evaluation of ready to eat black clam (Villorita cyprinoides) product in indigenous retort pouch, $J$. Food Eng. 2006; 7: 995-1000.

35. Mathews AR, Mahadevaih M, Gowaramma RV and MN Krishnamurthy Packaging of raw ground nut oil in tin-free steel cans. J. Food Sci. Technol. 1988; 35 (5): 435-437.

36. Aubourg SP, Sotelo CG and JM Gallards Changes in flesh lipids and fill oil of albacore (Thunnus alalunga) during canning and storage. J. Agric. Food Chem. 1990; 38 (3): 809-812.

37. Manju S, Sonaji ER, Jose L, Gopal TKS, Ravishankar CN and PK Vijayan Heat penetration characteristics and shelf life studies of seer fish moilee packed in retort pouch. Fishery Technol 2004; 41(1): 37-44. 
38. Tanaka $\mathbf{M}$ and $\mathbf{T}$ Taguchi Non-enzymatic browning during thermal processing of canned sardine. Bull. Japan Soc. Sci. Fish., 1985; 51 (7): 1169117.

39. Mahadevaiah M and RV Gowramma Food packaging materials; historical prospective, In: Food packaging materials. McGraw-Hill publishing Company Limited, New Delhi, 1996 Pp: 10-13. 